\title{
Warm Season Grain Legume Landraces From the South of Europe for Germplasm Conservation and Genetic Improvement
}

\section{OPEN ACCESS}

Edited by:

Spyridon Alexandros Petropoulos, University of Thessaly, Greece

Reviewed by: Deidre Fourie,

Agricultural Research Council of South Africa (ARC-SA),

South Africa Josefina Hernández Nistal, Universidade de Santiago de Compostela, Spain

*Correspondence: Antonio M. De Ron amderon@mbg.csic.es

Specialty section: This article was submitted to Crop and Product Physiology, a section of the journa Frontiers in Plant Science

Received: 04 July 2018 Accepted: 28 September 2018 Published: 22 October 2018

Citation: De Ron AM, Bebeli PJ, Negri V, Vaz Patto MC and Revilla P (2018)

Warm Season Grain Legume Landraces From the South of Europe for Germplasm Conservation and Genetic Improvement.

Front. Plant Sci. 9:1524. doi: 10.3389/fp/s.2018.01524

\section{Antonio M. De Ron ${ }^{1 *}$, Penelope J. Bebeli ${ }^{2}$, Valeria Negri ${ }^{3}$, Maria Carlota Vaz Patto ${ }^{4}$ and Pedro Revilla ${ }^{1}$}

'Department of Genetics and Plant Breeding, Misión Biológica de Galicia, National Spanish Research Council (CSIC), Pontevedra, Spain, ${ }^{2}$ Laboratory of Plant Breeding and Biometry, Department of Crop Science, Agricultural University of Athens, Athens, Greece, ${ }^{3}$ Dipartimento di Scienze Agrarie, Alimentari e Ambientali, Università degli Studi di Perugia, Perugia, Italy, ${ }^{4}$ Instituto de Tecnologia Química e Biológica António Xavier, Universidade Nova de Lisboa, Oeiras, Portugal

Currently, there is a high concern from consumers regarding food quality, with emphasis on the origin of food sources. We here review the current situation of beans (Phaseolus spp.) and cowpea (Vigna unguiculata (L.) Walp.) landraces in the South of Europe focusing on morpho-agronomic and genetic diversity and physiological adaptation to the different agrosystems, including the symbiotic association with rhizobia. Despite the reduction in the production and consumption of grain legumes in Southern Europe, the variability of common bean, runner bean and cowpea landraces in this region is adequately preserved ex situ in germplasm banks and in breeder collections in Portugal, Spain, Italy and Greece; however, on-farm (in situ) conservation in isolated areas mainly in gardens and small fields for farmers own consumption and local markets is not guaranteed. This variability can be used for the genetic improvement of varieties, which will result in environmental-friendly improved legumes for a sustainable production in the South of Europe as well as in other regions of the World.

Keywords: adaptation, diversity, breeding, populations, Phaseolus, physiology, plant genetic resources, Vigna unguiculata

\section{LEGUME LANDRACES}

Food legumes are an important component of human diet and life for their contribution as source of protein but also for their support to the environment sustainability through the biological symbiotic fixation of nitrogen, and the enhancement of the ecosystem services because some of them are bee pollinated (De Ron, 2015; Suso et al., 2016). In the South of Europe, beans and cowpea are relevant nutritional and environmental resources well adapted to their agrosystem that should be genetically preserved and improved for their efficient use.

Landraces are traditional crop varieties or populations growing in specific locations and constitute valuable sources for breeding purposes as basic genetic material to obtain improved elite varieties. Usually a landrace is a mixture of a number of distinct homozygous lines in the case of self-pollinating crops (common bean, Phaseolus vulgaris L. and cowpea, Vigna unguiculata (L.) Walp.) (Raggi et al., 2013). In the case of cross-pollinated crops (runner or scarlet bean P. coccineus L.), the landraces are populations with more heterozygous components (Newton et al., 2010). They are maintained by farmers according to their preferences and the adaptation to their environment in ecological key areas. Merging several definitions (Spataro and Negri, 2013), a landrace can be 
defined as a "variable population, which is identifiable and usually has a local name, lacks formal crop improvement, is characterized by a specific adaptation to the environmental conditions of the cultivation area (tolerant to the biotic and abiotic physiological stresses of that area) and is closely associated with the uses, knowledge, habits, dialects, and celebrations of the people who have developed and continue to grow it" (Negri et al., 2009). As such, they are a cultural and biological diversity heritage of value for present and future generations.

Common bean, runner or scarlet bean and cowpea are the warm season Mediterranean legumes included in this review. Common bean is the most important food legume for direct human consumption on a global scale (De Ron et al., 2016a), while runner bean has a more limited cultivation. Cowpea is extensively cultivated in tropical and subtropical areas in Africa (especially in the Sub-Saharan Africa, SSA) and the Americas (Central and South America), but has limited importance in Southern Europe and in North America (De Ron, 2015).

These legumes could be used for fresh and dry seeds and fresh pods and they play an important role in the healthy European Mediterranean diet. Recently, the role of beans and other food legumes in human diet refers not only to its high protein content but also to the functional properties of some components that could contribute to reduce risk of several serious diseases (Hangen and Bennink, 2003; Thompson et al., 2009; Vaz Patto et al., 2015). Recent trends on legume nutritional quality key factors focus on new strategies to enhance consumer acceptance and improve legume functional properties.

In spite of the decrease of grain legumes cultivation and consumption in some countries of Europe in the last years (Figure 1), the interest in landraces of these crops has recently grown in Europe, as well as in other continents This is due to the need of having a more sustainable agriculture, meet the present environmental challenges, avoid further genetic erosion and satisfy consumer increasing request for healthy, environmentally friendly, local food (with reduced physiological carbon footprint since it is locally produced). Special mention deserves the varieties that are recognized with some figure of legal protection, such as quality labels [like the European Protected Designation of Origin (PDO), Protected Geographical Indication (PGI), and Traditional Specialties Guaranteed (TSG)]. However, the wide variability and the lack of uniformity for many morpho-agronomic traits in landraces is an obstacle for the application of the current legislation for their commercial or protected registration in some countries.

\section{EUROPEAN COWPEA AND BEAN LANDRACES EVOLUTION AND DISTINCTNESS FROM THE ORIGINAL GENEPOOLS}

Cowpea is the old "bean" that was grown by the Romans and Arabs (Álvarez de Morales, 2002). Domesticated in the SSA during the second millennium B.C., cowpea early spread in Asia and Europe, where it was grown by the Greeks in the third century B.C. and by the Romans in the first century based on the writings of Theophrastus and Plinius. With its spreading across the Old World, many different forms and landraces were developed also for this crop (Polegri and Negri, 2010).

Cowpea has been largely cultivated in the Old World, where this crop has a high cultural and socio-economic value for local communities (De Luca et al., 2018). Fresh pods of cowpea are consumed in Southern Europe, where a relatively large number of landraces has been developed, giving rise to a wide genotypic and phenotypic diversity among and within landraces (Lazaridi et al., 2017). These authors found that differences among cowpea landraces are not determined by the country of origin in Southern Europe. Neighbor landraces can be adequately distinguished even though there is a high level of diversity present within each landrace; consequently, the best strategy for maintaining diversity in an area is to preserve each of the landraces in the farms from which it came (Tosti and Negri, 2005).

After the initial domestication process in the Americas, the common and runner bean arrived in Spain and spread across Europe and later arrived in Africa (Gepts and Bliss, 1988; De Ron et al., 2015, 2016a). Since these species were originated and domesticated in tropical highlands, local widely different biotic and physiological abiotic conditions and farmer preferences and/or initial genetic bottleneck had a strong influence on the development of European landraces (Rodiño et al., 2006; Rodriguez et al., 2013; Raggi et al., 2014; Ferreyra et al., 2017) which resulted in a complex genetic structure of the bean germplasm and in a clear differentiation of the European gene pool with respect to the American genetic pools (Santalla et al., 2002; Angioi et al., 2010; Spataro et al., 2011; Rodriguez et al., 2013).

As for common bean in particular, no records of this crop have been found in European herbariums earlier than 1543; but, according to Zeven (1997), common bean was certainly widely grown in many areas of Europe in 1669. Of the many landraces found across Europe most belong to the Andean gene pool, being less represented the Mesoamerican gene pool (Rodiño et al., 2001; Angioi et al., 2010; Leitão et al., 2017). However, a relatively high proportion of the European common bean germplasm (33$44 \%$ ) appear to be derived from hybridization events between the Andean and Mesoamerican gene pools, when the landraces were grown in proximity, displaying novel genetic combinations not typical of the primary American centers of domestication and emphasizing the potential value of the European germplasm for breeding (Santalla et al., 2002; Angioi et al., 2010).

\section{ECO-PHYSIOLOGICAL ADAPTIVE TRAITS OF BEAN AND COWPEA IN THE SOUTH OF EUROPE}

The evolution of beans and cowpea in the South of Europe by their adaptation to the ecophysiological regional conditions has involved changes in landraces. In a study that included 10 cowpea landraces from the South of Europe (five from Portugal, three from Spain, and two from Greece) cultivated in three different locations for 2 years, Martos-Fuentes et al. (2017) displayed the 


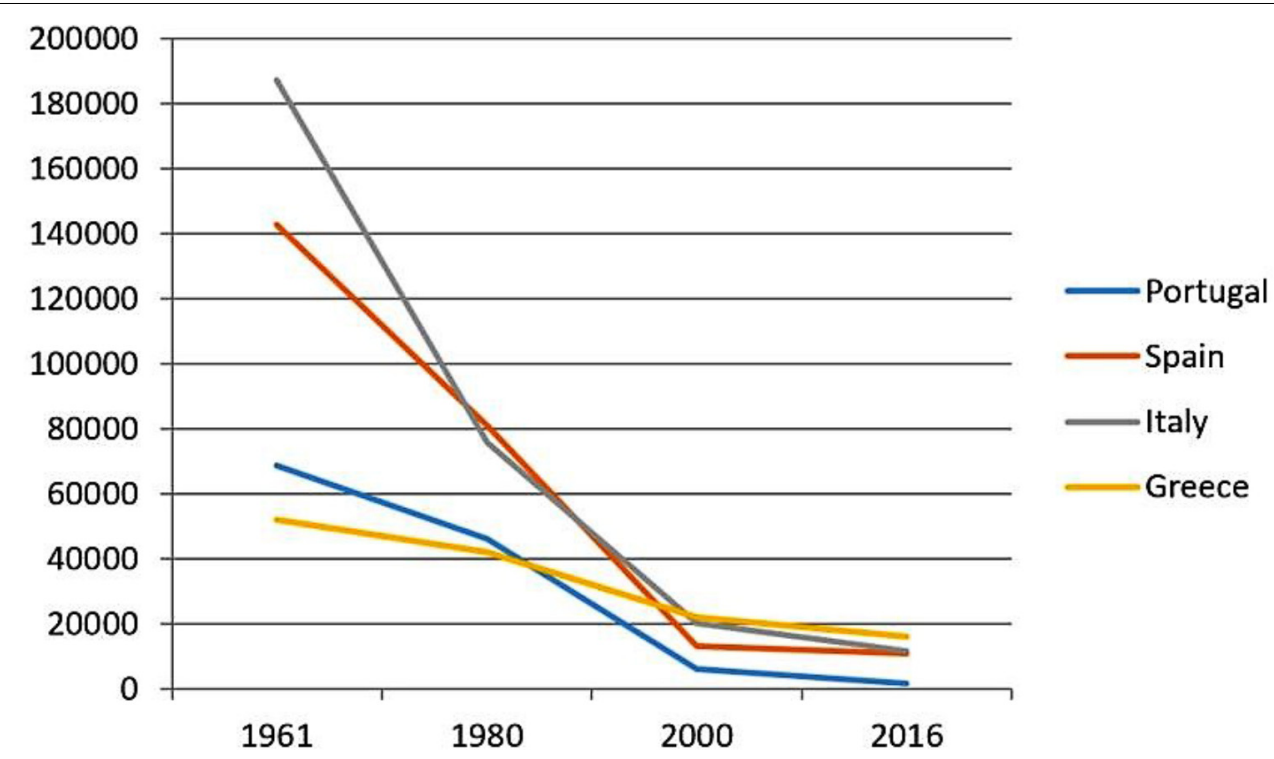

FIGURE 1 | Production (Mg/year) evolution of dry bean (Phaseolus vulgaris) in southern European countries (FAOSTAT, 2018).

existence of significant interactions among genotypes, locations and years, that is relevant in breeding for important agromorpho-physiological traits.

The diversity originated in cowpea along centuries is also important for the tolerance to local stresses that each local variety has developed due to natural selection for adaptation as well as farmer selection for agronomical applications and dietary benefits (De Luca et al., 2018).

\section{Low Temperature}

A desirable characteristic for crops is a rapid and homogeneous seed germination and emergence at different environmental conditions (Revilla et al., 2005). As other crops, there are differences among bean landraces regarding their performance (germination, seedling emergence, vegetative growth, flowering, and yield) in different environments and under different temperatures. There is a need of bean germplasm with the qualities of the grain demanded by consumers to increase the success and the added value of the bean crop; and the tolerance to low temperature after sowing at germination and emergence is a key characteristic for a good development of the crop. The eco-physiological response of beans to low temperature stress has been often studied under controlled environmental conditions in glasshouse and climatic chambers but the long-term main goal of genetic improvement for low temperature tolerance is the selection of landraces under different environmental temperatures in open field.

To analyze the response to a relevant eco-physiological condition as low temperature, De Ron et al. (2016b) performed several trials with 28 dry bean genotypes (21 landraces from Spain and Portugal and seven improved varieties from Spain, France and Japan) in open field under different temperature conditions in April (low temperature: $10-14^{\circ} \mathrm{C}$ ), May (moderate temperature: $12-17^{\circ} \mathrm{C}$ ) and June (warm temperature: $15-22^{\circ} \mathrm{C}$ ) in the North of Spain. The experiment was replicated in a growth chamber resembling the same environmental conditions. Three Spanish landraces (PHA399, PHA419, and PHA1058) and the improved variety Borlotto with low temperature stress-tolerance at seedling emergence, and high yield potential could be valuable genetic material for breeding programs. Seedling emergence of the large seeded landraces from Spain belonging to the Andean genetic pool was delayed compared to the small seeded landraces from the Mesoamerican one, in the controlled growth chamber and in the open field experiments, and they showed lower emergence in the open field under realistic agronomic conditions. This fact could be explained by the evolution of the common bean in the southwest of Europe, since farmers probably selected for years large seeded bean landraces due to their high market value and used to germinate the seeds in nurseries before transplanting the seedling into the open field and no breeding actions were taken by farmers and breeders to improve germination and emergence of the large-seeded Andean landraces under low temperatures in field.

The runner bean frequently requires moderate or warm temperatures for a good emergence and growth, while low temperature at sowing delays plant emergence and early growth, and can reduce establishment of the crop when an early sowing is carried out. Rodiño et al. (2007a) evaluated runner bean germplasm in a climate-chamber: 19 landraces from Spain and Portugal, four from Mexico, four from Rwanda and five commercial varieties. Best performers in emergence and first trifoliate leaf, traits related to earliness, were four Spanish and one Portuguese landraces compared to the Mexican ones that indicated a good adaptation of this genetic material to the ecophysiological conditions in the South of Europe.

Cowpea is considered a cold susceptible crop; however, cowpea is not being improved for cold tolerance. Modern breeding programs establish as key breeding objectives the 
development of drought tolerant, early maturing, pest tolerant and erect type cowpea in countries where this is an important crop, such as India (Roy et al., 2016). Since several years ago, some reports have found genetic diversity for cold tolerance in cowpea, e.g., El-Kholy et al. (1997) evaluated a collection of cowpea genotypes for cold tolerance at germination and found that genotypes differed in rate for leakage of electrolytes but not in maximal percentage of germination. The effects of cold conditions on crop development differ at diverse growth stages, from germination to reproduction. Under cold conditions in the field, reducing the seed moisture content results in decreased percentage of emergence and rapid electrolyte leakage in cowpea, while deep sowing results in slow and low percentage emergence (Ismail et al., 1997).

The genetic regulation of cold tolerance in cowpea has been scarcely studied; but several genes related to cowpea response to cold conditions have been identified (Tan et al., 2016). Ismail et al. (1997) proposed that cold tolerance at early stages of the crop is due to a seed dehydrin protein and can be explained by a single gene inheritance. These authors also reported that maternal gene effects are important for the electrolyte leakage of cowpea seeds at cold temperature, and appear to restrict their contribution to cold tolerance to the beginning of plant development. Although genetic diversity for cold tolerance is limited in cowpea, breeding cowpea for cold tolerance at germination has been successful (Ismail et al., 1997). Although some sources of cold tolerance have been identified, introgression of cold tolerance in elite germplasm is a challenge because cowpea is a mainly self-pollinating crop. Several major QTLs have been identified, even though the development of mapping populations is a difficult and timeconsuming task. Markers have not been actually used in breeding; nevertheless, novel techniques, such as developing transgenic plants, RNA-Seq, and reverse genetics open new opportunities for molecular breeding (Tan et al., 2016).

\section{Water Stress}

Water deficit is considered a relevant agronomic factor limiting crop productivity and is responsible for important yield reduction in many crops (Serraj et al., 2004). The severity of drought stress is always unpredictable as it depends on factors such as occurrence and distribution of rainfall, evaporative demands of the atmosphere and moisture storing capacity of the different soils.

In the common bean, the main selection criteria for drought resistance is the plant growth and the grain yield. Rodiño et al. (2007b) evaluated 21 common bean accessions (12 landraces from Spain and Portugal and nine resistant and susceptible cultivars) in two locations in the northwest of Spain to identify those genetic materials adequate for breeding for water deficit tolerance. The Drought Intensity Index (DII) was calculated as DII $=1-\mathrm{Xds} / \mathrm{Xns}$, being $\mathrm{Xds}$ and $\mathrm{Xns}$ the average of all the accessions under drought stress (DS) and no stress (NS) conditions. Drought Susceptibility Index (DSI) for each common bean accession was calculated following these formulae: DSI $=(1-\mathrm{Yds} / \mathrm{Yns}) / \mathrm{DII}$, where Yds and Yns are the average yields of an accession under DS and NS conditions. Five Spanish landraces (PHA432, PHA471, PHA543, PHA683, and PHA2074) had high level of drought resistance together with two cultivars (Alavesa and Linex). These results confirm that during its evolution in Europe some common bean landraces were able to adapt to different eco-physiological conditions, such as drought.

Moreover, the variability present in 23 cowpea landraces collected from Greek fields revealed potential germplasm for drought tolerance (Lazaridi et al., 2016). Cowpea is considered a legume tolerant to heat, drought and poor soils due to its capacity to fix nitrogen even under stress conditions (Carvalho et al., 2017a; Lazaridi et al., 2017). However, the diversity available for stress tolerance in southern Europe has neither been deeply studied nor used in breeding programs for stress tolerance. Shadeya et al. (2000) found limited diversity for drought tolerance in advanced breeding lines evaluated by a rapid laboratory method, but they were able to identify tolerant and susceptible genotypes that could be used for breeding. Genetic regulation of drought tolerance follows an additive - dominance model in most crops, including cowpea; being dominance and additive effects similar and important, while epistasis was rare, and narrow sense heritability was low to moderate for most traits under terminal water stress (Olajide and Ilori, 2018).

Drought effects in cowpea included reduction of plant growth, yield components, shoot and seed nutrients, and leaf water content, along with membrane instability; while increase activity of leaf antioxidant enzymes, content of leaf proline, electrolyte leakage, and shoot Si content (Merwad et al., 2018). Furthermore, leaf anatomical features are also altered by drought, being width of midvein and xylem, thickness of midvein, phloem and xylem tissues, and palisade and spongy tissues of leaf blade decreased (Merwad et al., 2018). Drought reduces plant cell water potential and turgor and raises solute concentrations. The water deficit had negative influence on mineral nutrition and metabolism decreases leaf area and alters assimilate partitioning among the organs. Physiological mechanisms of the plants for facing water stress include escape, avoidance by increasing the water uptake and reducing transpiration rate by maintaining tissue turgor by osmotic adjustment allowing the plants to preserve their vegetative growth, and resist the severe water stress by physiological mechanisms (Jones, 2004).

\section{Biological Nitrogen Fixation}

Legume biological Nitrogen $(\mathrm{N})$ fixation by symbiosis with soil rhizobia provides an eco-physiological and agronomic chance to increase common bean productivity related to soil fertility and climatic conditions. Miranda and Bliss (1991) reported that many common bean landraces have low biological $\mathrm{N}$ fixation capacity probably due to their original domestication process as a home garden crop, with low selection pressure for the improvement of the symbiotic association with rhizobia. Rodiño et al. (2011) studied 64 common bean landraces for their capacity to establish symbiosis with rhizobia in controlled conditions and the effect of the environmental conditions on the symbiotic efficiency of them in six environments in Spain. The variation among environments for nodulation efficiency among landraces was remarkable, and five of them (PHA175, PHA508, PHA525, PHA595, and PHA652) displayed good nodulation and high yield in field. 
The bean-rhizobia symbiotic system is usually affected by the water availability. Coleto et al. (2014) studied the inhibition of $\mathrm{N}$ fixation and ureide accumulation under water deficit in two common bean landraces and two breeding lines of contrasting drought tolerance. Their results displayed relevant genotypic differences in the drought sensitivity of biological $\mathrm{N}$ fixation among the landraces, and that the genetic variation is linked to ureide accumulation in the stressed leaves. In addition, two common bean landraces studied (PHA246 from Spain and PHA683 from Portugal) had better performance under DS than the tolerant breeding line used as check (Sea 5); therefore, their eco-physiological adaptation were reliable and they could be used in breeding programs designed to improve the efficiency of $\mathrm{N}$ biological fixation under water stress in common bean in the South of Europe.

De Ron et al. (2014) evaluated 10 common bean landraces from Spain and Portugal, together with some breeding lines tolerant to water deficit. This material was inoculated with 10 distinct strains of Rhizobium (eight local and two checks, $R$. tropici CIAT899 and $R$. etli CFN42) in greenhouse both under irrigation and water stress. Under water stress, five Spanish and one Portuguese landraces displayed high nodule number, high nodular biomass, a great uniformity in the caliber of their nodules, and a significant correlation with aerial biomass that is a relevant component of plant yield.

The results of these experiments showed that the common bean landraces are well adapted to their eco-physiological environments in the South of Europe and some of them are able to establish an efficient symbiosis with native rhizobia, even under water stress conditions.

Low soil fertility is a challenge for cowpea production, especially in low-input agriculture, which is the most common production system in undeveloped countries where this legume is a basic food supply. Fortunately, this crop has a great ability to synthetize $\mathrm{N}$ through the symbiotic interaction with rhizobia. Adaptation of cowpea includes coevolution with indigenous rhizobia associated with strains of the species Ensifer fredii that were able to nodulate and fix $\mathrm{N}$ in cowpea but not in soybean and common bean (Tampakaki et al., 2017). These authors conclude that the Ensifer isolates may constitute a new symbiovar for which they propose the name "aegeanense". Furthermore, symbiosis can partially explain the gains in breeding programs for agronomic performance; actually, Oruru et al. (2018) reported that modern cultivars of cowpea had higher root colonization, nodulation, and nutrients in the shoot than old cultivars and concluded that the response of mycorrhizal inoculation has been indirectly improved by selection for yield.

\section{MORPHO-AGRONOMIC AND GENETIC TRAITS OF BEAN AND COWPEA IN THE SOUTH OF EUROPE}

In the European Mediterranean basin, clearly differentiated common bean landraces exist, originated from populations firstly introduced in the Iberian Peninsula after the exploration of The Americas. A particular case is the white seed bean types from
Turkey that seem to be phylogenetically distant from the rest of the European germplasm, probably due to their introduction through East Asia via the Silk Route (De La Fuente et al., 2010).

There are great differences in the preferences of the bean markets and consumers in different countries and regions related to grain size, shape, color, and cooking time, therefore these types are described as "market classes" (Voysest, 2000; Santalla et al., 2001), usually including unimproved germplasm (landraces) and some improved varieties. Breeding for commercial varieties in beans within landraces of different market classes has the goals of improve the preferred seed size, shape, color, and pattern in each area of production. As mentioned above, in the South of Europe bean landraces appear to have experienced major phenomena of evolution and adaptation, as they show clear differences between them.

In Portugal, the national common bean production still depends considerably on landraces adapted to local conditions, and fulfilling specific morphological, agronomic and nutritional farmers' preferences in mainland north and central regions, Azores and Madeira Islands (Moreira and Veloso, 2009; Vaz Patto and Araújo, 2016). Currently there are some common bean cultivars (six landraces and two conservation varieties ("Corno de Carneiro" and "Tarrestre") registered at the Portuguese National Catalog (CNV, 2017). Based on morphological and reproductive traits, considerable diversity has been described among common bean landraces from the North of Portugal (Rodiño et al., 2001) and from Madeira Island (Freitas et al., 2010). In particular, different sources of resistance and partial resistance to rust and powdery mildew have been identified in a dedicated germplasm collection screening (Leitão et al., 2013), anticipating a high potential for disease resistance breeding in the Portuguese germplasm. The genetic variation of the Portuguese common bean accessions was also characterized using RAPD and SSR molecular markers (Martins et al., 2006; Leitão et al., 2017) not detecting clear relation between the geographic distribution and the genetic distance. This absence of relation may be due to an important genetic flow resulting from the traditional seed exchange practices at local markets or among farmers. Leitão et al. (2017) also positioned the Portuguese germplasm in the worldwide diversity of common bean through a SSR-based genetic diversity study involving an enlarged collection of Portuguese landraces from all traditional beangrowing geographical areas and wild relatives and representative accessions from the Andean and Mesoamerican gene pools. Structure analysis divided the collection into three main clusters, with most of the Portuguese accessions clustering with the Andean representatives, but one third of the analyzed national landraces might represent putative hybrids between American gene pools. Some core collections were developed by the same authors maximizing the genetic and morphological diversity of the original collection, and representing the Portuguese common bean accessions with the minimum redundancy.

In Spain many common bean landraces have been collected in farmer fields, starting from the 70's of the last century and are conserved ex situ in the national gene bank (CRFINIA, Alcalá de Henares) as well as in breeders collections in different regions, while many landraces can still be found 
cultivated in situ (on-farm) in some places mainly for own or local markets consumption. Six areas of Spain have landraces or local varieties awarded with quality labels (PDO and PGI), including 16 common bean and one runner bean, while no cowpea variety is recognized with these labels. The most appreciated landraces or local varieties are white large and extra-large seeded (50-100 g 100 seeds $^{-1}$ ) (Santalla et al., 2005), generally belonging to the Andean gene pool, although some of them are intermediate or recombinant types with the Mesoamerican pool (Santalla et al., 2002).

In Italy over 200 common bean landraces are officially recorded as maintained in situ (Negri et al., 2013) with six of them awarded with PDO or PGI. An analysis of 146 Italian landraces based on the combined use of morpho-physiological, biochemical and molecular traits clearly distinguished almost each landrace from the others (Raggi et al., 2013). It also showed that the Italian landrace genetic diversity is clearly structured in three clusters and that clustering is not simply ascribable to the original Mesoamerican and Andean gene pools, similarly to what was found in the Portuguese germplasm by Leitão et al. (2017). On the contrary, the distinction of cluster 1 from cluster 2 appeared to be (at least partially) due to adaptation (for flowering date and resistance/tolerance to diseases) to the different environmental conditions that are determined by altitude since the presence of selective effects was detected for some of the SSR used in the study. Breeding activities have been intense in the past years since beans are largely cultivated for both the seed and the pod consumption in Italy: twenty-eight cultivars have been released by a Ministry of Agriculture Research Center (CREA_CI, A. Carboni pers. comm.). Most of them were specifically bred for resistance to the main biotic stress of the crop (which are striking on intensive cultivations) and mostly relying on alien germplasm since landraces, although giving product of high organoleptic quality, are poorly adapted to intensive cultivation
(Parisi and Campion, 2010). However, to breed lines specifically suited to organic agriculture we can well take advantage of landrace germplasm (Caproni et al., 2018).

In Greece bean landraces have been collected in organized expeditions particularly during the previous century and are conserved ex situ in many genebanks while several landraces can still be found cultivated on-farm in many places mainly for own or local consumption. The dry beans of several Greek Phaseolus spp. landraces have been characterized as PDO or PGI having added value that resulted in the need for testing the authenticity of their products and the development of test methods based on molecular tools (Ganopoulos et al., 2012). Improved cultivars bred in Greece are either selections from Greek landraces or selections following crosses between landraces and introduced germplasm. Characterization and evaluation of common bean landraces and main improved varieties cultivated in Greece using morpho-agronomical, physicochemical traits, sensory and molecular data showed a wide (among and within landraces) genetic variation and also revealed promising landraces with superior yield components and protein content that could be used "per $s e$ " or in breeding programs for conventional or low input/organic cultivation (Mavromatis et al., 2010; Vakali et al., 2017).

As for runner beans, different landraces are also cultivated in Spain, Portugal, and Italy (Santalla et al., 2004; Spataro et al., 2011; Rodriguez et al., 2013; Schwember et al., 2017), and in the North of Greece where two groups can be distinguished depending on seed dimensions ("giants" with 100 seed weight range from 120 to $180 \mathrm{~g}$ and "elephants" with 100 seed weight outreaches the $180 \mathrm{~g}$ ).

Cowpea is currently a crop of minor importance for Europe; however, considering its greater drought resistance in comparison with common bean and a scenario of climate change and unpredictability, it is likely to have an increased

TABLE 1 | Warm season legume landraces ex situ collections in the South of Europe.

\begin{tabular}{|c|c|c|}
\hline Country & National collections (gene banks) & Breeder collections and features \\
\hline Portugal & $\begin{array}{l}\text { Portuguese Plant Germplasm Bank, BPGV } \\
\text { (Braga, Portugal, FAO code PRT001; now } \\
\text { conserving also the previous INIAV Research } \\
\text { Unit of Biotechnology and Genetic Resources } \\
\text { collection, FAO code PRT005). Conserving } \\
3307 \text { common bean and } 344 \text { cowpea } \\
\text { accessions. }\end{array}$ & \\
\hline Spain & $\begin{array}{l}\text { National Center for Plant Generic Resources } \\
\text { (CRF-INIA, FAO code ESP004). Conserving } \\
3616 \text { Common bean, } 121 \text { runner bean and } 487 \\
\text { cowpea accessions. }\end{array}$ & $\begin{array}{l}\text { MBG-CSIC (FAO code ESP009) (De Ron et al., } \\
\text { 2018). Conserving } 1701 \text { Spanish and other } \\
\text { origins common bean, } 49 \text { Spanish runner bean } \\
\text { and } 89 \text { Spanish and Portuguese cowpea } \\
\text { accessions (De Ron et al., 2003). }\end{array}$ \\
\hline Italy & $\begin{array}{l}\text { UNIPG-DSA3 (FAO code ITA363) and other } \\
\text { Italian collections (See } \\
\text { https://www.crea.gov.it/853/plantares/ for } \\
\text { details on number of conserved accessions). }\end{array}$ & $\begin{array}{l}\text { Common bean 552, runner bean } 91 \text { and } \\
\text { cowpea } 16 \text { accessions. }\end{array}$ \\
\hline Greece & $\begin{array}{l}\text { Greek Genebank (FAO code GRC005). } \\
\text { Conserving } 436 \text { common bean, } 30 \text { runner bean } \\
30 \text { and } 37 \text { cowpea accessions (Katsiotis et al., } \\
\text { 2009). }\end{array}$ & \\
\hline
\end{tabular}


importance in future years. For instance, Portugal has presently one cowpea cultivar ("Fradel") registered at the National Catalog for commercial use (CNV, 2017) although many varieties are available commercially. Cowpea cultivation is mostly based on landraces and scientific studies have been carried out to assess breeding potentialities of local germplasm (Negri et al., 2000, 2001; Lazaridi et al., 2016, 2017; Carvalho et al., 2017a,b; Karapanos et al., 2017; Martos-Fuentes et al., 2017). The characterization of fresh pod traits in thirty-one cowpea landraces from Portugal, Spain and Greece revealed promising variation for production (Lazaridi et al., 2017).

From all the above, we may conclude that Southern Europe is still rich in landrace diversity maintained ex situ and in situ which represents an important source of interesting plant traits combinations, not yet fully explored in formal genetic improvement programs. According to the PGR Genesys (2018) database the landraces of warm season legumes landraces from the South of Europe maintained in genebanks are: 11371 of common bean, 1442 of runner bean and 940 of cowpea. In situ wealth of landrace diversity is presently threatened by the replacement by novel, genetically uniform cultivars, the possible general effects of climate change in plant physiology and growth, the aging of farmers and ineffective transmission of knowledge related to landraces, the desertion of the land caused by migration from rural areas to cities, the internationalization of food systems and the pressure of changing markets with restrictive food standards.

However, it should be noted that some of the numerous landraces of warm season legumes were/are being awarded of EU quality marks (27, including both common and runner bean) and/or are promoted as typical product locally. This helps, at least partially, halting the loss of useful germplasm and its evolution in situ. The on farm conservation of landraces could be guaranteed if it offers an income to the farmers. This can be achieved by marketing the landraces products emphasizing their uniqueness with special brand names that highlight their local cultural heritage (Karanikolas et al., 2017). Additionally, in situ conservation can be accomplished by supporting farmers willing to cultivate the traditional varieties, for example with a participatory plant breeding program, or even with financial support when the genetic resources are considered as national patrimony.

\section{CONCLUDING REMARKS}

According to the available data, the variability of the common bean, runner bean and cowpea landraces from the South of Europe is adequately preserved ex situ in germplasm banks and in breeders collections in Portugal, Spain, Italy and Greece (Table 1); however, on-farm or in situ conservation in isolated areas mainly in gardens and small fields for farmers own consumption and local markets is not guaranteed currently. In addition, this variability is being used for the genetic improvement of varieties, some of them already registered and others protected by quality labels, despite the reduction in the production and consumption of grain legumes in those areas. Legume research programs in Europe are only focussed to cowpea pre-breeding, even though this crop could make significant contributions to legume production in arid areas.

The genetic structure of landrace populations, in the case of autogamous species such as common bean and cowpea, gives an opportunity for individual selection within landraces adapted to particular eco-physiological conditions with the objective of obtaining improved breeding lines that could be used per se for production or as basic germplasm for breeding programs. In the case of the runner bean, an allogamous species, individual selection must include isolation because of the role of insects in the reproductive process.

To take full advantage of these valuable bean and cowpea adapted landrace resources it is extremely important to complement the existing molecular/morpho-physiological diversity analysis with detailed phenotypic evaluations, and to enhance the symbiotic system legume-rhizobia for an efficient biological $\mathrm{N}$ fixation. These will allow the identification of landraces with increased market value (adapted to biotic and physiological stresses or characterized by market quality traits) that can actively be used to overcome different constraints affecting both production and consumption. It will result in obtaining environmental-friendly improved legumes for a sustainable production in the South of Europe and for other regions of the World.

\section{AUTHOR CONTRIBUTIONS}

$\mathrm{ADR}, \mathrm{PB}, \mathrm{VN}, \mathrm{MVP}$, and PR equally contributed to the conception of the work, revising the work, and approval of the version to be published.

\section{FUNDING}

Research was supported by the projects RFP2013-00001 and RFP105-0008 from the Spanish Government and AGI/CSICI + D + I. OTR00114 from the Galician Government CSIC (Spain), IF/01337/2014 and UID/Multi/04551/2013 from Fundação para a Ciência e Tecnologia (Portugal). ADR and PR acknowledge support of the publication fee by the CSIC Open Access Publication Support Initiative through its Unit of Information Resources for Research (URICI).

\section{ACKNOWLEDGMENTS}

The authors are grateful to CRF-INIA (Alcalá de Henares, Spain), Polytechnic University of Cataluña (Barcelona, Spain), and SERIDA (Villaviciosa, Spain) for supplying common bean runner bean and cowpea germplasm, and Diputación de Pontevedra (Pontevedra, Spain) for farm facilities. 


\section{REFERENCES}

Álvarez de Morales, C. (2002). "Agrónomos andalusíes y sus legados," in La Herencia Árabe en la Agricultura y el Bienestar de Occidente, ed. F. Nuez (Valencia: Editorial Universidad Politécnica de Valencia), 1-69.

Angioi, S., Rau, D., Attene, G., Nanni, L., Bellucci, E., Logozzo, G., et al. (2010). Beans in Europe: origin and structure of the European landraces of Phaseolus vulgaris L. Theor. App. Genet. 121, 829-843. doi: 10.1007/s00122-010-1353-2

Caproni, L., Raggi, L., Tissi, C., Howlett, S., Torricelli, R., and Negri, V. (2018). Multi-environment evaluation and genetic characterisation of common bean breeding lines for organic farming systems. Sustainability 10, 1-17. doi: 10. 3390/su10030777

Carvalho, M., Bebeli, P. J., Pereira, G., Casgro, I., Egea-Gilabert, C., Matos, M., et al. (2017a). European cowpea landraces for a more sustainable agriculture system and novel foods. J. Sci. Food Agric. 97, 4399-4407. doi: 10.1002/jsfa.8378

Carvalho, M., Muñoz-Amatriaín, M., Castro, I., Lino-Neto, T., Matos, M., EgeaCortines, M., et al. (2017b). Genetic diversity and structure of Iberian Peninsula cowpeas compared to world-wide cowpea accessions using high density SNP markers. BMC Genomic 18:891. doi: 10.1186/s12864-017-4295-0

CNV (2017). Catálogo Nacional de Variedades. Direcção Geral da Alimentação e Veterinária (DGAV). Ministério da Agricultura, Florestas e Desenvolvimento Rural. Portugal. Available at: www.drapc.minagricultura.pt/base/documentos/cnv_2017.pdf [accessed May 23, 2018].

Coleto, I., Pineda, M., Rodiño, A. P., De Ron, A. M., and Alamillo, J. (2014). Comparison of inhibition of $\mathrm{N} 2$ fixation and ureide accumulation under water deficit in four common bean genotypes of contrasting drought tolerance. Ann. Bot. 113, 1071-1082. doi: 10.1093/aob/mcu029

De La Fuente, M., De Ron, A. M., Rodiño, A. P., and Santalla, M. (2010). Evolution of the European bean from their American ancestors. Annu. Rept. Bean Improv. Coop. 53, 34-35.

De Luca, D., Cennamo, P., Del Guacchio, E., Di Novella, R., and Caputo, P. (2018). Conservation and genetic characterisation of common bean landraces from Cilento region (southern Italy): high differentiation in spite of low genetic diversity. Genetica 146, 29-44. doi: 10.1007/s10709-017-9994-6

De Ron, A. M. (2015). Grain Legumes. Series: Handbook of Plant Breeding. New York: Springer Science + Business Media, doi: 10.1007/978-1-49392797-5

De Ron, A. M., De la Rosa, L., and Marcos, T. (2018). Current situation of the bean germplasm collections in Spain. Annu. Rept. Bean Improv. Coop. 61, 53-54.

De Ron, A. M., González, A. M., Monteagudo, A. B., Lema, M., and Santalla, M. (2003). Colección de Vigna spp. de la MBG-CSIC. Act. Assoc. Esp. Legum. 2, 121-123.

De Ron, A. M., González, A. M., Rodiño, A. P., Santalla, M., Godoy, L., and Papa, R. (2016a). History of the common bean crop: its evolution beyond its areas of origin and domestication. Arbor 192:a317. doi: 10.3989/arbor.2016.779n3007

De Ron, A. M., Rodiño, A. P., Santalla, M., González, A. M., Lema, M. J., Martín, I., et al. (2016b). Seedling emergence and phenotypic response of common bean germplasm to different temperatures under controlled conditions and in open field. Front. Plant Sci. 7:1087. doi: 10.3389/fpls.2016.01087

De Ron, A. M., Papa, R., Bitocchi, E., González, A. M., Debouck, D. G., Brick, M. A., et al. (2015). "Common Bean," in Grain Legumes. Series: Handbook of Plant Breeding, ed. A. M. De Ron (New York, NY: Springer Science + Business Media), 1-36. doi: 10.1007/978-1-4939-2797-5-1

De Ron, A. M., Rodiño, A. P., and Riveiro, M. (2014). Analysis of the symbiotic system bean-rhizobia under water stress conditions in greenhouse. Annu. Rept. Bean Improv. Coop. 57, 99-100.

El-Kholy, A. S., Hall, A. E., and Mohsen, A. A. (1997). Heat and chilling tolerance during germination and heat tolerance during flowering are not associated in cowpea. Crop Sci. 37, 456-463. doi: 10.2135/cropsci1997. 0011183X003700020025x

FAOSTAT (2018). Available at: http://www.fao.org/faostat/en/\#data/QC [accessed May 12, 2018].

Ferreyra, M., Menéndez-Sevillano, M. C., Ibarra, L. R., and De Ron, A. M. (2017). Characterization of wild common bean populations for their in situ conservation in Northwestern Argentina. Euphytica 213:186. doi: 10.1007/ s10681-017-1954-9

Freitas, G., Ganança, J. F. T., Nóbrega, H., Nunes, E., Costa, G., Slaski, J. J., et al. (2010). Morphological evaluation of common bean diversity on the Island of Madeira. Genet. Resour. Crop Evol. 58, 861-874. doi: 10.1007/s10722-010-9624y

Ganopoulos, I., Bosmali, I., Madesis, P., and Tsaftaris, A. (2012). ). Microsatellite genotyping with HRM (High Resolution Melting) analysis for identification of the PGI common bean variety Plake Megalosperma Prespon. Eur. Food Res. Technol. 234, 501-508. doi: 10.1007/s00217-011-1653-z

Gepts, P., and Bliss, F. A. (1988). Dissemination pathways of common bean (Phaseolus vulgaris, Fabaceae) deduced from phaseolin electrophoretic variability. II. Europe and Africa. Econ. Bot. 42, 86-104. doi: 10.1007/ BF02859038

Hangen, L., and Bennink, M. R. (2003). Consumption of black beans and navy beans (Phaseolus vulgaris) reduced azoxymethane-induced colon cancer in rats. Nutr. Cancer 44, 60-65.

Ismail, A. M., Hall, A. E., and Close, T. J. (1997). Chilling tolerance during emergence of cowpea associated with a dehydrin and slow electrolyte leakage. Crop Sci. 37, 1270-1277. doi: 10.2135/cropsci1997.0011183X003700040041x

Jones, H. (2004). "What is water use efficiency?," in Water Use Efficiency in Plant Biology, ed. M. A. Bacon (Oxford: Blackwell), 27-41.

Karanikolas, P., Bebeli, P. J., and Thanopoulos, R. (2017). Farm economic sustainability and agrobiodiversity: identifying viable farming alternatives during the economic crisis in Greece. J. Environ. Econ. Policy 7, 69-84. doi: $10.1080 / 21606544.2017 .1360212$

Karapanos, I., Papandreou, A., Skouloudi, M., Makrogianni, D., Fernández, J. A., Rosa, E., et al. (2017). Cowpea fresh pods - a new legume for the market: assessment of their quality and dietary characteristics of 37 cowpea accessions grown in southern Europe. J. Sci. Food Agric. 97, 4343-4352. doi: 10.1002/jsfa. 8418

Katsiotis, A., Mavromatis, A., Bebeli, P., and Tzivelikas, A. (2009). "An inventory of Greek landraces," in European Landraces: On-farm Conservation, Management and Use, eds M. Vetelainen, V. Negri, and N. Maxted (Rome: Bioversity Int. Publications), 97-104.

Lazaridi, E., Ntatsi, G., Fernández, J. A., Karapanos, I., Carnide, V. P., Savvas, D., et al. (2017). Phenotypic diversity and evaluation of fresh pods of Southern European cowpea (Vigna unguiculata (L.) Walp.) landraces. J. Sci. Food Agric. 97, 4265-4655. doi: 10.1002/jsfa.8249

Lazaridi, E., Ntatsi, G., Savvas, D., and Bebeli, P. J. (2016). Diversity in cowpea (Vigna unguiculata (L.) Walp.) local populations from Greece. Genet. Resour. Crop Evol. 64, 1529-1551. doi: 10.1007/s10722-016-0452-6

Leitão, S. T., Almeida, N. F., Moral, A., Rubiales, D., and Vaz Patto, M. C. (2013). Identification of resistance to rust (Uromyces appendiculatus) and powdery mildew (Erysiphe diffusa) in Portuguese common bean germplasm. Plant Breed. 132, 654-657. doi: 10.1111/pbr.12094

Leitão, S. T., Dinis, M., Veloso, M. M., Satovic, Z., and Vaz Patto, M. C. (2017). Establishing the bases for introducing the unexplored Portuguese common bean germplasm into the breeding world. Front. Plant Sci. 8:1296. doi: 10.3389/ fpls.2017.01296

Martins, S. R., Vences, F. J., Sáenz de Miera, L. E., Barroso, M. R., and Carnide, V. (2006). RAPD analysis of genetic diversity among and within Portuguese landraces of common white bean (Phaseolus vulgaris L.). Sci. Hort. 108, 133142. doi: 10.1016/j.scienta.2006.01.031

Martos-Fuentes, M., Fernández, J. A., Ochoa, J., Carvalho, M., Carnide, V., Rosa, E., et al. (2017). Genotype by environment interactions in cowpea (Vigna unguiculata L. Walp.) grown in the Iberian Peninsula. Crop Pasture Sci. 68, 924-931. doi: 10.1071/CP17071

Mavromatis, A. G., Arvanitoyannis, I. S., Korkovelos, A. E., Giakountis, A., Chatzitheodorou, V. A., and Goulas, C. K. (2010). Genetic diversity among common bean (Phaseolus vulgaris L.) Greek landraces and commercial cultivars: nutritional components, RAPD and morphological markers. Spanish J. Agric. Res. 8, 986-994. doi: 10.5424/sjar/2010084-1245

Merwad, A. R. M. A., Desoky, E. S. M., and Rady, M. M. (2018). Response of water deficit-stressed Vigna unguiculata performances to silicon, proline or 
methionine foliar application. Sci. Hort. 228, 132-144. doi: 10.1016/j.scienta. 2017.10.008

Miranda, B. D., and Bliss, F. A. (1991). Selection for increased seed nitrogen accumulation in common bean: implications for improving dinitrogen fixation and seed yield. Plant Breed. 106, 301-311. doi: 10.1111/j.1439-0523.1991. tb00515.X

Moreira, P. M. R. M., and Veloso, M. M. (2009). "Landrace inventory for Portugal," in European Landraces On-farm Conservation, Management and Use, Vol. 15, eds M. Vetelainen, V. Negri, and N. Maxted (Rome: Bioversity International), 124-136.

Negri, V., Floridi, S., and Montanari, L. (2001). Organoleptic and chemical evaluation of Italian cowpea (Vigna unguiculata subsp. unguiculata (L) Walp.) landraces from a restricted area. Italian J. Food Sci. 13, 383-390.

Negri, V., Maxted, N., and Vetelainen, M. (2009). European landrace conservation: an introduction. Bioversity Techn. Bull. 15, 1-22.

Negri, V., Pacicco, L., Bodesmo, M., and Torricelli, R. (2013). The First Italian Inventory of in Situ Maintained Landraces. On CD ROM. ISBN 978-88-6074279-7. Perugia: Morlacchi Editrice.

Negri, V., Tosti, N., Falcinelli, M., and Veronesi, F. (2000). Characterization of thirteen cowpea landraces from Umbria (Italy) Strategy for their conservation and promotion. Genet. Resour. Crop Evol. 47, 141-146. doi: 10.1023/A: 1008714108583

Newton, A. C., Akar, T., Baresel, J. P., Bebeli, P. J., Bettencourt, E., Bladenopoulos, K. V., et al. (2010). Cereal landraces: an essential resource for the future of contemporary agriculture, A review. Agron. Sustain. Dev. 30, 237-269. doi: 10.1051/agro/2009032

Olajide, A. A., and Ilori, C. O. (2018). Genetic analysis of seedlings characters associated with drought tolerance in cowpea under a controlled environment. Plant Gen. Res. Charac. Util. 16, 218-227. doi: 10.1017/S14792621170 00235

Oruru, M. B., Njeru, E. M., Pasquet, R., and Runo, S. (2018). Response of a wild-type and modern cowpea cultivars to arbuscular mycorrhizal inoculation in sterilized and non-sterilized soil. J. Plant Nutr. 41, 90-101. doi: 10.1080/ 01904167.2017.1381728

Parisi, B., and Campion, B. (eds). (2010). Il Fagiolo: Consiglio per la Ricerca e la Sperimentazione in Agricoltura Edizioni. Montanaso Lombardo: Cartaceo.

PGR Genesys (2018). Available at: www.genesys-pgr.org [accessed May 28, 2018].

Polegri, L., and Negri, V. (2010). Molecular markers for promoting agrobiodiversity conservation: a case study from Italy. How cowpea landraces were saved from extinction. Genet. Resour. Crop Evol. 57, 867-880. doi: 10.1007/ s10722-009-9526-z

Raggi, L., Tiranti, B., and Negri, V. (2013). Italian common bean landraces: diversity and population structure. Genet. Resour. Crop Evol. 60, 1515-1530. doi: 10.1007/s10722-012-9939-y

Raggi, L., Tissi, C., Mazzucato, A., and Negri, V. (2014). Molecular polymorphism related to flowering trait variation in a Phaseolus vulgaris L. collection. Plant Sci. 21, 180-189. doi: 10.1016/j.plantsci.2013.11.001

Revilla, P., Butrón, A., Cartea, M. E., Malvar, R. A., and Ordás, A. (2005). "Breeding for cold tolerance," in Abiotic Stresses: Plant Resistance Through Breeding and Molecular Approaches, eds M. Ashraf and P. J. C. Harris (New York, NY: The Harworth Press), 301-398.

Rodiño, A. P., De La Fuente, M., De Ron, A. M., Lema, M. J., Drevon, J. J., and Santalla, M. (2011). Variation for nodulation and plant yield of common bean genotypes and environmental effects on the genotype expression. Plant Soil 346, 349-361. doi: 10.1007/s11104-011-0823-x

Rodiño, A. P., Lema, M., Pérez-Barbeito, M., Santalla, M., and De Ron, A. M. (2007a). Assessment of runner bean (Phaseolus coccineus L.) germplasm for tolerance to low temperature during early seedling growth. Euphytica 155, 63-70. doi: 10.1007/s10681-006-9301-6

Rodiño, A. P., Riveiro, M., Santalla, M., and De Ron, A. M. (2007b). Sources of variation of common bean for drought tolerance. Annu. Rept. Bean Improv. Coop. 50, 163-164.

Rodiño, A. P., Santalla, M., González, A. M., De Ron, A. M., and Singh, S. P. (2006). Novel genetic variation in common bean from the Iberian Peninsula. Crop Sci. 46, 2540-2546. doi: 10.2135/cropsci2006.02.0104

Rodiño, A. P., Santalla, M., Montero, I., Casquero, P. A., and De Ron, A. M. (2001). Diversity in common bean germplasm (Phaseolus vulgaris L.) from Portugal. Genet. Resour. Crop Evol. 48, 409-417. doi: 10.1023/a:1012248002436
Rodriguez, M., Rau, D., Angioi, S., Bellucci, E., Bitocchi, E., Nanni, L., et al. (2013). The European Phaseolus coccineus L. landraces: population structure and adaptation, as revealed by of cpSSRs, nuSSRs and phenotypic analyses. PLoS One 8:e57337. doi: 10.1371/journal.pone.0057337

Roy, A. K., Malaviyal, D. R., and Kaushal, P. (2016). Genetic improvement of fodder legumes especially dual purpose pulses. Indian J. Genet. Plant Breed. 76, 608-625. doi: 10.5958/0975-6906.2016.00076.6

Santalla, M., De Ron, A. M., and Voysest, O. (2001). "European bean market classes," in Catalogue of Bean Genetic Resources, eds M. Amurrio, M. Santalla, and A. M. De Ron (Pontevedra: Fundación Pedro Barrié de la Maza), 77-94.

Santalla, M., González, A. M., Lema, M., Rodiño, A. P., Monteagudo, A. B., and De Ron, A. M. (2005). Improvement of large-seeded common bean cultivars under sustainable cropping systems in Spain. Euphytica 142, 85-95. doi: 10. 1007/s10681-005-0816-z

Santalla, M., Monteagudo, A. M., González, A. M., and De Ron, A. M. (2004). Agronomical and quality traits of runner bean germplasm and implications for breeding. Euphytica 135, 205-215. doi: 10.1023/B:EUPH.0000014912. 07993.e7

Santalla, M., Rodiño, A. P., and De Ron, A. M. (2002). Allozyme evidence supporting southwestern Europe as a secondary center of genetic diversity for common bean. Theor. Appl. Genet. 104, 934-944. doi: 10.1007/s00122-0010844-6

Schwember, A. R., Carrasco, B., and Gepts, P. (2017). Unraveling agronomic and genetic aspects of runner bean (Phaseolus coccineus L.). Field Crops Res. 206, 86-94. doi: 10.1016/j.fcr.2017.02.020

Serraj, R., Krishnamurthy, L., Kashiwagi, J., Kumar, J., Chandra, S., and Crouch, J. H. (2004). Variation in root traits of chickpea (Cicer arietinum L.) grown under terminal drought. Field Crops Res. 88, 115-127. doi: 10.1016/j.fcr.2003. 12.001

Shadeya, L., Akundabweni, M., Monti, L., and Fonzo, D. (2000). Detached leaf test as a rapid stress appraisal in cowpea germplasm, Vigna unguiculuta ((L) Walp) for drought resistance. Disc. Innovat. 12, 132-136. doi: 10.4314/dai.v12i3. 15578

Spataro, G., and Negri, V. (2013). The European seed legislation on conservation varieties: focus, implementation, present and future impact on landrace on farm conservation. Genet. Resour. Crop Evol. 60, 2421-2430. doi: 10.1007/s10722013-0009-x

Spataro, G., Tiranti, B., Arcaleni, P., Bellucci, E., Attene, G., Papa, R., et al. (2011). Genetic diversity and structure of a worldwide collection of Phaseolus coccineus L. Theor. Appl. Genet. 122, 1281-1291. doi: 10.1007/s00122-011-1530-y

Suso, M. J., Bebeli, P. J., Christmann, S., Mateus, C., Negri, V., Pinheiro de Carvalho, M., et al. (2016). Enhancing legume ecosystem services through an understanding of plant-pollinator interplay. Front. Plant Sci. 7:333. doi: 10. 3389/fpls.2016.00333

Tampakaki, A., Fotiadis, C. T., Ntatsi, G., and Savvas, D. (2017). A novel symbiovar (aegeanense) of the genus Ensifer nodulates Vigna unguiculata. J. Sci. Food Agric. 97, 4314-4325. doi: 10.1002/jsfa.8281

Tan, H. Q., Huang, H. T., Tie, M., Tang, Y., Lai, Y., and Li, H. (2016). Transcriptome profiling of two asparagus bean (Vigna unguiculata subsp. sesquipedalis) cultivars differing in chilling tolerance under cold stress. Plos One 11:e0151105. doi: 10.1371/journal.pone.0151105

Thompson, M. D., Brick, M. A., McGinley, J. N., and Thompson, H. J. (2009). Chemical composition and mammary cancer inhibitory activity of dry bean. Crop Sci. 49, 179-186. doi: 10.2135/cropsci2008.04. 0218

Tosti, N., and Negri, V. (2005). On-going on-farm microevolutionary processes in neighbouring cowpea landraces revealed by molecular markers. Theor. Appl. Genet. 110, 1275-1283. doi: 10.1007/s00122-0051964-1

Vakali, C., Baxevanos, D., Vlachostergios, D., Tamoutsidis, E., Papathanasiou, F., and Papadopoulos, I. (2017). Genetic characterization of agronomic, physiochemical, and quality parameters of dry bean landraces under low-input farming. J. Agr. Sci. Tech. 19, 957-967.

Vaz Patto, M. C., Amarowicz, R., Aryee, A., Boye, J., Chung, H. J., MartínCabrejas, M. A., et al. (2015). Achievements and challenges in improving the nutritional quality of food legumes. Crit. Rev. Plant Sci. 34, 105-143. doi: $10.1080 / 07352689.2014 .897907$ 
Vaz Patto, M. C., and Araújo, S. S. (2016). Positioning Portugal into the context of world production and research in grain legumes. Rev. Ciências Agrárias 39, 3-21. doi: 10.19084/RCA 16161

Voysest, O. (2000). Mejoramiento Genético Del Frijol (Phaseolus vulgaris L.). Legado de Variedades de América Latina 1930-1999. Cali: CIAT.

Zeven, A. C. (1997). The introduction of the common bean (Phaseolus vulgaris L.) into Western Europe and the phenotypic variation of dry beans collected in The Netherlands in 1946. Euphytica 94, 319-328. doi: 10.1023/A:10029402 20241
Conflict of Interest Statement: The authors declare that the research was conducted in the absence of any commercial or financial relationships that could be construed as a potential conflict of interest.

Copyright $\odot 2018$ De Ron, Bebeli, Negri, Vaz Patto and Revilla. This is an open-access article distributed under the terms of the Creative Commons Attribution License (CC BY). The use, distribution or reproduction in other forums is permitted, provided the original author(s) and the copyright owner(s) are credited and that the original publication in this journal is cited, in accordance with accepted academic practice. No use, distribution or reproduction is permitted which does not comply with these terms. 